\section{European summit}

\section{Unanimity but little of substance}

EUROPEAN leaders confronted with the massive overproduction and costs of the Common Agricultural Policy and the need for technological cooperation to face competition from the United States and Japan, laboured mightily to produce a mouse last week: an anodyne communiqué, the result of the London summit marking the last month of Britain's sixmonth presidency of the European Communities, which failed to mention agriculture at all, put off budget questions to a later summit, and included lukewarm support for research in Europe only on the last-minute insistence of the French President, François Mitterand.

This time, the presidents, prime ministers and chancellors of the 12 states of the European Communities were in no mood to tackle controversial topics, at least in public. Foreign Office sources in London indicated not entirely in jest that the present disablement of the US presidency over the Iran arms sales affair, and the confusions over US defence policy, obliged Europe to present a united face to Moscow: squabbling in the Community would not help. Moreover, Chancellor Helmut Kohl of West Germany faces general elections next month, so this was not the best time to ask him to be hard on his farming voters. Prime Minister Jacques Chirac of France was preoccupied with the student protests (and late on Friday, the death of a student) in Paris; and the United Kingdom, meanwhile, did not want to bow out of the presidency on a sour note after its efforts these six months to prove itself a hard-working, constructive member of Europe.

The resulting bland unity was not good news for the research programme of the Communities' think-tank and administration, the European Commission, which the Commission has proposed to double. Jacques Delors, Commission president, had hoped the summit could send a strong signal in favour of the programme to the research ministers, who were to meet on Tuesday. During the summit, Delors emerged to say that many delegations had stressed the importance of the Commission's 'framework programme' for research and "approved it totally". Finally, however, the summit communiqué merely "urged" research ministers to agree, but gave no indication on the level of spending on which agreement should be reached, the matter which seemed likely to be the final sticking point on Tuesday between the big three - Britain, France and Germany - which oppose the proposed increases, and the rest, which support them.

President Mitterrand, pressed on the research question after the summit - as he had been the first to introduce such matters to summitry - claimed credit that any clause on research at all had been introduced into the communiqué. The British Prime Minister, Margaret Thatcher, also questioned on research, avoided the matter of budgets and stressed the high technology equipment. She singled out the need for a common standard on digital cellular radio. This relatively small item was also the only technology explicitly mentioned in the communique for action, leaving the question of whether the leaders might actually have had in mind the need for common standards in the more ramifying systems of integrated digital services networks.

The European leaders also reached agreement to designate 1989 European Cancer Information Year to develop a "sustained and concerted information campaign ... on the prevention, early warning and treatment of cancer". No mention was made of possible concerted action on tobacco advertising, but the ministers undertook to "follow up" the recommendations of a committee of European experts which is due shortly to report on cancer prevention to the Commission. A programme on AIDS (acquired immune deficiency syndrome) was also agreed, but this was only to compare notes on actions taken by the different member states in public information and prevention. The possibility of "further cooperation in research" on AIDS was to be considered by health ministers, the leaders agreed.

Robert Walgate importance of agreement on standards for
Washington

LAST week the threatened Superconducting Super-Collider (SSC) project cleared one of its major political hurdles by gaining approval from John Herrington, the first Energy Secretary to endorse SSC since the agency began work on the programme five years ago.

It is a change of heart as only a month ago Herrington claimed that his mind was not made up on the advisability of the project. But because of the enormous cost, now estimated to be about $\$ 3,000$ million, formal approval would have to come from the White House Office of Management and Budget (OMB). According to sources at the Energy Department, Herrington has not yet formally met top OMB officials.

Alvin Trivelpiece, director of the Energy Department's Office of Energy Research, has been trying to get other countries to participate in SSC, but such commitments are difficult if the United States is hesitant. Trivelpiece says Japan may invest $\$ \mathbf{5 0 0}$

\section{Independence for UK space centre?}

ThE British National Space Centre (BNSC) is pressing the government to give it financial independence and to allocate an annual space budget of about $£ 200$ million without channelling it through other government bodies. The proposals for the budget and plan are at present being discussed at cabinet level.

The proposal for direct support accompanies the 15-year BNSC plan, and would allow more flexibility in managing the UK space effort. At present, the centre is funded by the Department of Trade and Industry, the Department of Education and Science and the Ministry of Defence.

The BNSC plan would increase spending on space, now $£ 108$ million, to about $£ 200$ million a year within three or four years. The plan has four principal ingredients and puts heavy emphasis on European collaboration. The first part of the space plan recommends strong British participation in the US Space Station and in a polar platform.

The second plank of the plan will ensure the development of new launchers, independently of the United States. Ariane V would form part of that project together with cheaper forms of space transport, including the European space shuttle HERMES and the British Aerospace/Rolls Royce space-plane HOTOL. The plan also includes an expanded space applications programme - Earth observation, microgravity and the like - as well as more space science research. Studies of solar plasma, geophysics and astronomy would also feature in this programme. Bill Johnstone

\title{
Super-collider still fighting for funds
}

million in the project. The Soviet Union is another potential participant. For the time being, potential partners from Western Europe have their hands full with LEP and DESY.

While approval from the Reagan administration is a necessary step for the project to proceed, it is far from sufficient. Many believe that the brake on spending achieved by the current Congress was achieved by adopting financial tactics such as delaying payments and selling assets. Any further reductions will require real programme cuts.

Congressional enthusiasm for the National Institutes of Health shows no sign of diminishing, and the administration is rumoured to be considering a large increase in the budget for the National Science Foundation and a request for more funds for the Strategic Defense Initiative. It is uncertain whether spending on SSC will prove to be any more politically attractive. Joseph Palca 